\title{
The Effect of Bacteriophage $\lambda$ on Host Cell Reactivation in Escherichia coli $\mathrm{K} 12$
}

\author{
By M. G. R. HART \\ Department of Botany, The Queen's University, Belfast, Northern Ireland
}

(Accepted for publication 3 September 1966)

SUMMARY

Host cell reactivation (hcr) of phage $\mathrm{T} 1$ by two strains of Escherichia coli $\mathrm{K} 12$, Hfr C $\left(\lambda^{+}\right)$thy $y^{-}$and Hfr B $1\left(\lambda^{-}\right)$thy $y^{-}$, was studied. Strain Hfr C showed decreased ability to reactivate ultraviolet (u.v.)-irradiated phage T1, as predicted from its behaviour in mating experiments after thymine starvation. Thymine starvation of host Hfr B 1 bacteria resembled u.v. irradiation in decreasing hcr, but thymine starvation of Hfrc increased hcr, apparently as a result of $\lambda$ induction. The presence of $\lambda$ prophage in $E$. coli $\mathrm{K} 12$ was found to decrease hcr.

\section{INTRODUCTION}

In examining the effects of intranuclear ${ }^{32} \mathrm{P}$ decay in Escherichia coli $\mathrm{K} 12$, Jacob \& Wollman (1958) were able to infer the presence of chromosome breaks in Hfr nuclei by examining the frequency with which various genetic markers were transferred to $\mathrm{F}^{-}$ recipients. Donor bacteria in which ${ }^{32} \mathrm{P}$ disintegration had occurred showed an altered gradient of transfer: the frequency of transfer of genetic markers distal to the chromosomal origin relative to the transfer of markers near to the origin was lower with ${ }^{32} \mathrm{P}$-damaged donor bacteria than with normal bacteria. The extent to which transfer of distal markers was reduced was proportional to their distance from the origin and to the fraction of ${ }^{32} \mathrm{P}$ which had distintegrated at the time of transfer. This reduction of the frequency of transfer of distal markers was called 'marker inactivation' and was thought to be due to interruptions in the transfer process resulting from breaks in the donor chromosome.

A recent examination of the effects of thymine starvation on the gradient of genetic transfer by Escherichia coli $\mathrm{K} 12$ strains $\mathrm{Hfr}$ в 1 thy $y^{-}$and $\mathrm{Hfr} \mathrm{C}$ thy $\mathrm{y}^{-}$revealed that the strains differ in their response (Hart, 1966). 'Marker inactivation' was obtained in experiments in which $\mathrm{Hfr}$ в 1 thy- was starved of thymine before mating but the gradient of transfer by Hfr $\mathrm{C}$ thy- in similar experiments was unaffected. It was suggested that single-strand gaps in the chromosome might be developed as a result of the excision of primary genetic lesions accompanying thymine starvation. In the absence of thymine these gaps would not be closed by synthesis of new DNA and a blockage of chromosome transfer similar to that which occurs after intranuclear ${ }^{32} \mathrm{P}$ decay (Jacob \& Wollman, 1958) might result. In a strain unable to modify the primary genetic lesions chromosome transfer would occur with normal kinetics as in donor bacteria irradiated with ultraviolet (u.v.) (Jacob \& Wollman, 1958).

Because of the numerous observations already made on the similarities between the effects of thymine starvation and u.v. irradiation (Coughlin \& Adelberg, 1956; Gallant

Vol. 46, No. 2, was issued 7 March 1967 
\& Suskind, 1961 ; Rassmussen \& Painter, 1963; and Drs K. A. Stacey, N. D. Symonds \& C. Atkinson, private communication) it was thought likely that any difference between the capacity of the two strains to modify genetic lesions might be detected in their ability to repair u.v. radiation damage. In the present investigation a comparison of the u.v. sensitivity and dark repair capacity of the two strains has been made and the effect of thymine starvation on the activity of the repair systems has been observed.

Escherichia coli $\mathrm{K} 12$ strain Hfr $\mathrm{C}$ thy $y^{-}$is lysogenic for phage $\lambda$, whereas strain Hfr B 1 thy $y^{-}$is $\lambda$ - $\lambda$-resistant and it was therefore anticipated that the Hfr $\mathrm{C}$ strain would show greater sensitivity to direct u.v. irradiation. However, since the induced bacteria were thought to make no contribution to the recombination data obtained previously (in mating experiments with thymine-starved $\mathrm{Hfr} \mathrm{C}$ ) there remained the possibility that the sensitivity of the lysogenic strain might be compounded of the lethal effect of $\lambda$ induction and a deficiency in dark repair mechanisms. It is not possible to estimate the lethal effect of induction from the numbers of infective centres in an induced population since these are also subject to the lethal action of the inducing agent. The efficiency of dark repair was therefore estimated by examining the extent of host cell reactivation (Garen \& Zinder, 1955; Harm, 1963) of u.v.-irradiated T1 bacteriophage.

\section{METHODS}

Organisms and media. The bacterial strains, media and culture methods used were as described previously (Hart, 1966). Escherichia coli $\mathrm{K} 12$ strains $\mathrm{Hfr} \mathrm{H}\left(\lambda^{+}\right)$and $\mathrm{Hfr} \mathrm{H}\left(\lambda^{-}\right)$, which were kindly supplied by Dr W. Hayes, and strains AB 1157 (u.v. resistant$u v r^{+}$) and $\mathrm{AB} 1886\left(u v r^{-}\right)$(Howard-Flanders, Simpson \& Theriot, 1964), which were kindly supplied by Dr K. A. Stacey, were also used. Escherichia coli B was obtained from the National Collection of Industrial Bacteria.

Ultraviolet irradiation. Bacteria and phage were suspended in buffer ( $3 \mathrm{~g} . \mathrm{KH}_{2} \mathrm{PO}_{4}$; 7 g. $\mathrm{Na}_{2} \mathrm{HPO}_{4}$ anhy.; 4 g. $\mathrm{NaCl} ; 0 \cdot 2 \mathrm{~g} . \mathrm{MgSO}_{4} .7 \mathrm{H}_{2} \mathrm{O}$; distilled water to 11 .) and irradiated at $10 \mathrm{~cm}$. distance from a Hanovia Chromatolite u.v. lamp.

Bacteriophage techniques were those of Adams (1959). Pre-absorption of phage to bacteria was done in $\mathrm{T} 1$ absorption medium with $0.002 \mathrm{M}-\mathrm{KCN}$ according to the method of Sauerbier (1961). Experiments were performed by the light of a green safelight to avoid photo-reactivation.

\section{RESULTS}

Ultraviolet sensitivity and host cell reactivation of Escherichia coli $\mathrm{K} 12$ strains $H f r C\left(\lambda^{+}\right)$and Hfr $B 1\left(\lambda^{-}\right)$

Figure $1 a$ shows the sensitivity of the two strains to direct u.v. irradiation. In Fig. $1 b$ the survival of u.v.-irradiated phage T 1 plated on the two different strains is plotted against the dose of u.v. radiation. The phage was much more susceptible to small doses of u.v. radiation when plated on strain Hfr $\mathrm{C}\left(\lambda^{+}\right)$than when plated on strain Hfr B $1\left(\lambda^{-}\right)$, but additional irradiation gave the same additional kill, regardless of the plating bacterium used. For comparison the survival of irradiated phage T1 on Escherichia coli B was tested and found to be identical with that on strain Hfr B 1 . Strain Hfr $\mathrm{C}\left(\lambda^{+}\right)$was thus less able to compensate for u.v. damage to phage T 1 and this may account for the absence of marker inactivation in mating experiments after 
thymine starvation of this strain. However, the increased sensitivity of phage $\mathrm{T} 1$ on strain Hfr $\mathrm{C}$ is clearly not the result of a simple loss of uvr activity, which causes an increase in the rate constant for the decline in the $\log$ fraction of phage $\mathrm{T} 1$ surviving (Howard-Flanders et al. 1962). Further investigation will be necessary before the difference can be attributed to an excision defect.

\section{Effect of thymine starvation of host bacteria on the survival of u.v.-irradiated phage $T 1$}

If the products of thymine starvation are subject to the activity of u.v. repair systems, then thymine starvation of host bacteria might resemble u.v. irradiation (Garen \& Zinder, 1955; Tessman \& Ozaki, 1957) in decreasing the ability of the host
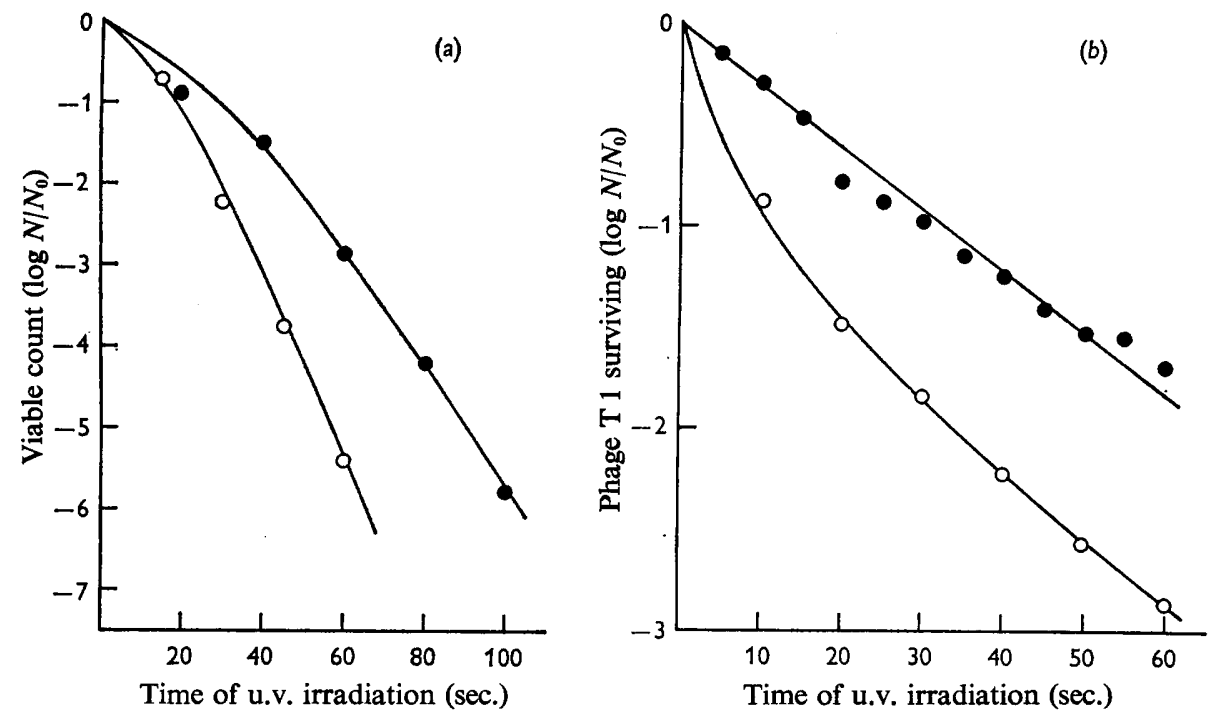

Fig. 1. (a) Ultraviolet irradiation: survival curves of Escherichia coli $\mathrm{K} 12$ strains $\mathrm{Hfr}$ в $1\left(\lambda^{-}\right)$ thy-, - ; Hfr $\mathrm{c}\left(\lambda^{+}\right)$thy $y^{-}, \mathrm{O}-\mathrm{O}$. (b) Ultraviolet radiation survival of phage $\mathrm{T} 1$ plated on the two strains. Symbols as in $(a)$.

Table 1. Effect of thymine starvation on the ability of E. coli $\mathrm{K} 12$ strain Hfr ${ }_{B} 1$ thy- to support growth of irradiated T1 bacteriophage

Viable phage particles $/ \mathrm{ml}$.

\begin{tabular}{|c|c|c|c|c|}
\hline \multirow[b]{2}{*}{ Plating bacteria } & \multicolumn{2}{|c|}{ Normal T 1} & \multicolumn{2}{|c|}{ T 1 irradiated $60 \mathrm{sec}}$. \\
\hline & Expt. 1 & Expt. 2 & Expt. 1 & Expt. 2 \\
\hline $\begin{array}{l}\text { Log phase Hfr B } 1 \\
\text { Hfr B1 starved of } \\
\text { thymine } 180 \mathrm{~min} .\end{array}$ & $\begin{array}{l}1.3 \times 10^{7} \\
4.5 \times 10^{6}\end{array}$ & $\begin{array}{l}1.4 \times 10^{6} \\
7 \cdot 0 \times 10^{5}\end{array}$ & $\begin{array}{l}2.5 \times 10^{5} \\
1.9 \times 10^{4}\end{array}$ & $\begin{array}{l}1.3 \times 10^{4} \\
6.2 \times 10^{2}\end{array}$ \\
\hline Ratio: $t h y^{-} /$thy $y^{+}$ & 0.35 & 0.50 & 0.08 & 0.05 \\
\hline
\end{tabular}

to repair u.v.-induced lesions in $\mathrm{u} . \mathrm{v}$.-irradiated $\mathrm{T} 1$ phage. Table 1 shows the results of two experiments in which normal and irradiated phage $\mathrm{T} 1$ was pre-absorbed on normal strain Hfr в 1 thy- bacteria and on Hfr B 1 thy- bacteria starved of thymine for $180 \mathrm{~min}$. and then plated in the normal way. In both experiments a loss in bacterial 
viability of more than two $\log$ units occurred after $180 \mathrm{~min}$. of thymine starvation. Thymine-starved host bacteria showed a marked decrease in their ability to support the multiplication of irradiated phage $T 1$, whereas a comparatively small effect of thymine starvation was noted when bacteria were infected with un-irradiated $\mathrm{T} 1$ phage. This result was confirmed by subjecting phage $\mathrm{T} 1$ to different degrees of u.v. irradiation and pre-absorbing to host bacteria previously thymine starved for $180 \mathrm{~min}$. The results of several experiments are collected in Fig. $2 a$ and $b$. Figure $2 a$ shows the survival of irradiated phage T1 on thymine-starved and normal Escherichia coli $\mathrm{K} 12$ Hfr в 1 thy-bacteria. Figure $2 b$ is constructed from the results of identical experiments with strain $\mathrm{Hfr} \mathrm{C}$ thy ${ }^{-}$. The results with Hfr в 1 were analogous to those obtained with
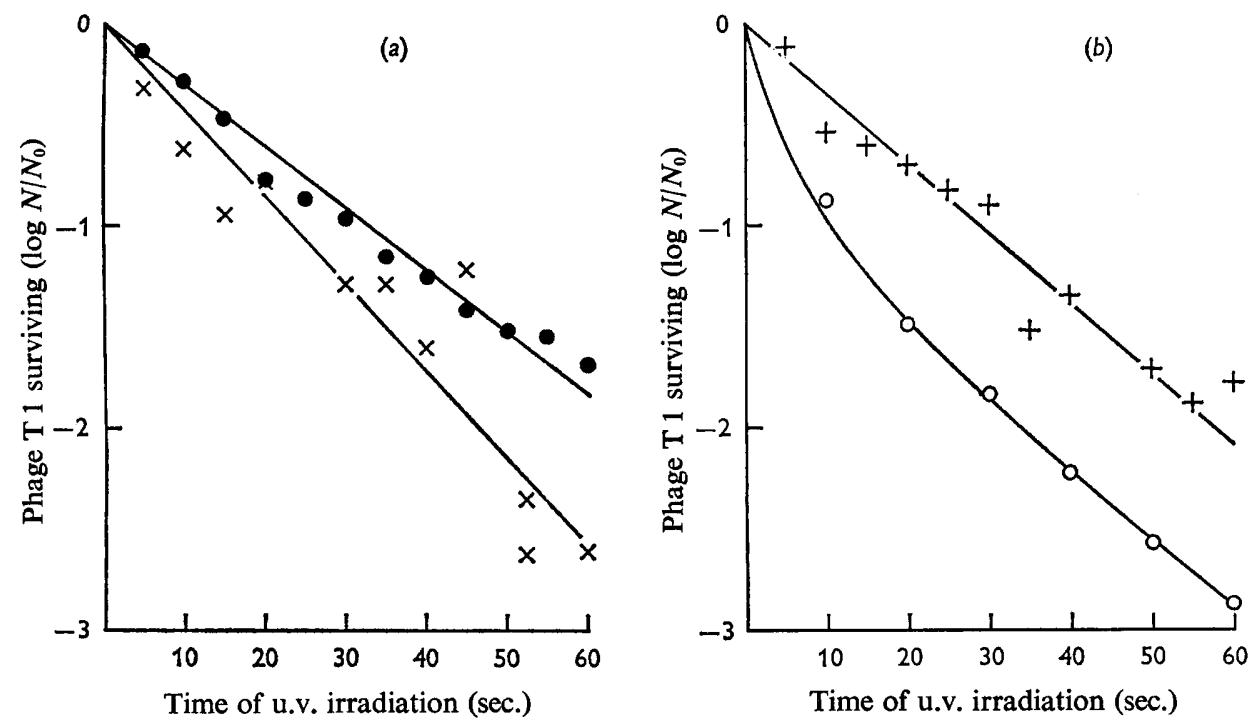

Fig. 2. (a) Ultraviolet irradiation: survival of phage T1 plated on E. coli $\mathrm{K} 12 \mathrm{Hfr} \mathrm{B} 1\left(\lambda^{-}\right)$thy $y^{-}$ without thymine starvation, - ; or pre-absorbed on the same strain starved of thymine for 180 min., $\times-\times$. The difference between the slopes is statistically significant at the $5 \%$ level. (b) As (a) but with $E$. coli $\mathrm{K} 12$ strain $\mathrm{Hfr} \mathrm{c}\left(\lambda^{+}\right)$thy- without thymine starvation, $\mathrm{O}-\mathrm{O}$; and with thymine stavation, +-+ .

u.v. irradiation: thymine starvation of the host bacteria decreased the plating efficiency of irradiated phage as compared with plating on unstarved bacteria. It had been anticipated that strain Hfr $\mathrm{c}$ would show a smaller or nil effect under these conditions. The increase in the ability of this strain to repair T1 damage which occurred on thymine starvation was entirely unexpected and suggested that phage $\lambda$ might be affecting repair mechanisms. The induction of $\lambda$ which occurs as a result of thymine starvation had apparently allowed multiplication of u.v.-radiation-damaged phage $T 1$ particles which were normally excluded from multiplication in the un-induced host. The survival of U.v.-irradiated phage $\mathrm{T} 1$ on thymine-starved $\mathrm{Hfr} \mathrm{c}$ bacteria was comparable to that found on normal strain Hfr в 1 . 


\section{Comparison of survival of u.v.-irradiated phage $T 1$ plated on Escherichia coli $\mathrm{K} 12$ strains lysogenic and non-lysogenic for phage $\lambda$}

The effect of $\lambda$ prophage in decreasing the efficiency of plating of u.v.-irradiated phage T 1 was confirmed by using Escherichia coli strains $\mathrm{Hfr} \mathrm{H}\left(\lambda^{+}\right)$and $\mathrm{Hfr} \mathrm{H}_{(-)}$ and a strain of Hfr $\mathrm{C}$ thy ${ }^{-}$which had been cured of $\lambda$ by selection after a heavy dose of u.v. radiation; the results are shown in Fig. $3 a$ and $b$. The differences noted between $\lambda^{+}$and $\lambda^{-}$strains were of the same order as those observed between Hfr $\mathrm{C}\left(\lambda^{+}\right)$and Hfr B $1\left(\lambda^{-}\right)$(Fig. $\left.1 b\right)$ and it is clear that the presence of $\lambda$ prophage in the host had a marked effect on the survival of irradiated phage T1. Escherichia coli strain HfrC appeared to give a greater overall sensitivity than did strains $\mathrm{Hfr} \mathrm{H}, \mathrm{Hfr} \mathrm{B} 1$ and $\mathrm{AB} 1157$, which were also tested.
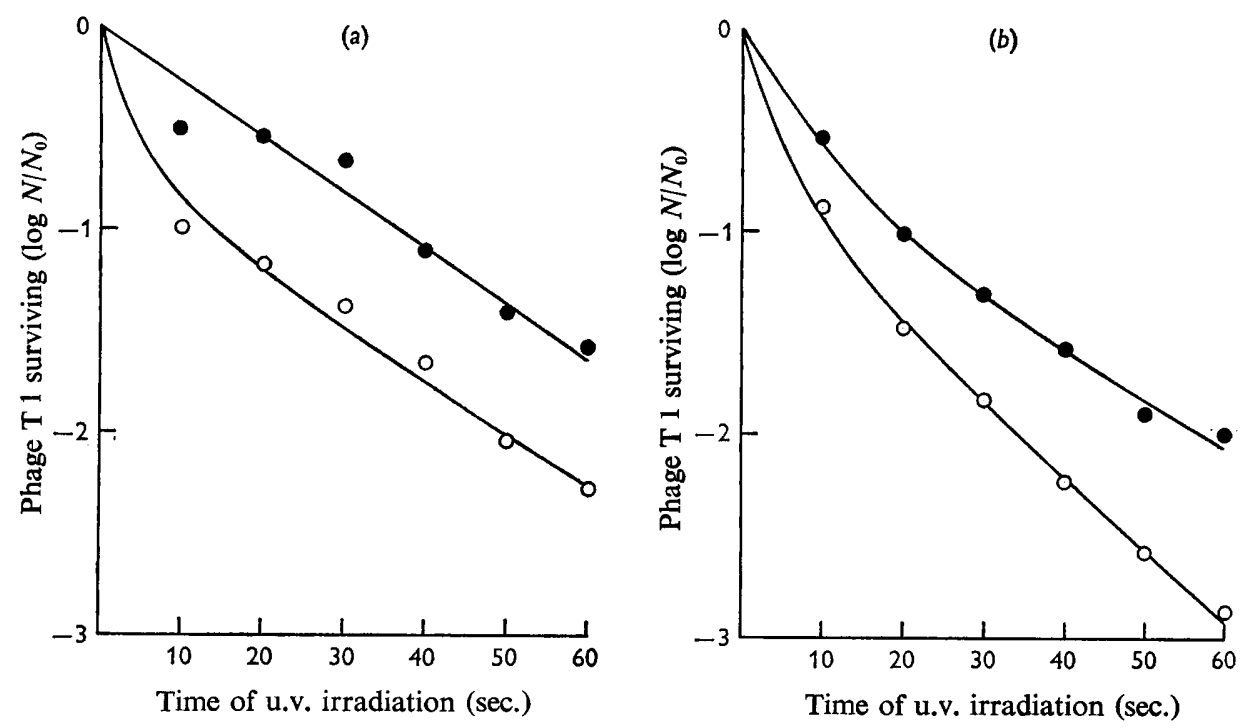

Fig. 3. (a) Ultraviolet irradiation: survival of phage T1 plated on $E$. coli $\mathbf{K} 12$ strain Hfr $\mathbf{H}$ $\left(\lambda^{+}\right), \mathrm{O}-\mathrm{O}$; on strain $\mathrm{Hfr} \mathrm{H}\left(\lambda^{-}\right)$, Oplated on $E$. coli $\mathrm{K} 12$ strain Hfr $\mathrm{C}\left(\lambda^{+}\right) t h y^{-}, \mathrm{O}-\mathrm{O}$; on the cured strain Hfr $\mathrm{C}\left(\lambda^{-}\right) t h y^{-}$, -10.

\section{DISCUSSION}

The present results go some way towards confirming the suggestion that thymine starvation of Escherichia coli strains resembles u.v. irradiation, causing genetic damage of a kind which can be modified by dark repair systems. If the increased sensitivity of irradiated phage $\mathrm{T} 1$ on $\lambda^{+}$strains of $E$. coli can be shown to be due to decreased ability to excise damaged DNA, then the production of single-strand gaps by excision in the absence of DNA synthesis would provide an adequate explanation of marker inactivation observed in thymine-starved Hfr B $1\left(\lambda^{-}\right)$and of its absence in Hfr C $\left(\lambda^{+}\right)$(Hart, 1966).

The influence of $\lambda$ prophage on dark repair of irradiated phage $\mathrm{T} 1 \mathrm{might}$ be a side effect resulting from the presence of the $\lambda$ episome on the bacterial chromosome: phage $\lambda$ is closely linked with the $u v r \mathrm{~B}$ gene (Howard-Flanders et al. 1964). 
Alternatively, it might be directly connected with the mechanisms of $\lambda$ immunity and prophage maintenance.

The probability that thymine starvation results in excision places this starvation in the company of other agents also known to be inducers of $\lambda$ prophage, namely ultraviolet radiation (Setlow \& Carrier, 1961), mitomycin C and nitrogen mustard (Boyce \& Howard-Flanders, 1964) and X-rays (Howard-Flanders et al. 1962). Induction of $\lambda$ might occur by excision of the prophage from its point of attachment on the bacterial chromosome. Inducing agents, all of which are known to have the property of causing genetic damage, may share the ability to de-repress a bacterial excision system maintained at a lesser degree of activity by the $\lambda$ repressor. The inducibility of repair systems in general is supported by the existence of 'u.v. reactivation' (Harm, 1963).

It is also possible to speculate on the involvement of similar mechanisms in $\lambda$ immunity. The increased sensitivity to u.v. irradiation of phage T1 plated on $\lambda^{+}$ strains of Escherichia coli differed from the uniform increased sensitivity obtained by plating on a $u r^{-}$mutant such as $\mathrm{AB} 1886$ (Howard-Flanders et al. 1962). In the $\lambda^{+}$ strains, a small dose of u.v. radiation results in the rapid development of strain sensitivity in a large fraction of the phage particles, but at larger doses the size of the sensitive fraction remains constant (Fig. $3 a$ ) and subsequent decline in the log fraction surviving occurs at the same rate on both strains. This would suggest that low doses of u.v. radiation may alter the DNA of some of the phage T1 particles so that they are incapable of multiplying in $\lambda^{+}$cytoplasm but can do so in $\lambda$ - cytoplasm or in induced (thymine-starved) $\lambda^{+}$cytoplasm. In fact, the $\lambda^{+}$bacterium may be 'immune' to the u.v.-modified phage T1, and the mechanism which prevents multiplication of superinfecting $\lambda$ might likewise prevent multiplication of u.v.-damaged phage $T 1$. A bacterial excision system could thus be responsible for: $(a)$ removing the prophage from its attachment site and allowing its replication; $(b)$ removing from exogenous $\lambda$ some modified portion of DNA which prevents replication. Both of these functions might be controlled by the $\lambda$ repressor in $\lambda^{+}$bacteria. At the present stage the evidence is not sufficiently detailed to allow adequate discussion of this model, which is compatible with most of the information at present available on the behaviour of $\lambda$ and its mutants. However, it predicts that a class of u.v.-sensitive bacterial mutants should exist which when $\lambda^{-}$behave as $\lambda$-resistant to all except $\lambda_{v}$ mutants, and when $\lambda^{+}$ behave as ind ${ }^{-}$. These would be defective in the bacterial gene which codes for the excision enzyme. Mattern, van Winden \& Rorsch (1965), who examined a number of $h c r^{-}$mutants of $E$. coli, found that they could be lysogenized and were more sensitive to induction by u.v. irradiation. These results are not compatible with the idea of excision playing an essential role in $\lambda$ induction and immunity, and the exact mechanism of the $\lambda$-induced decrease in host bacterium reactivation will have to be determined before its importance can be assessed.

The author thanks Mr M. H. L. Green for helpful discussions of these problems and $\mathrm{Mr}$ R. N. Laverty for technical assistance. 


\section{REFERENCES}

Adams, M. H. (1959). The Bacteriophages. New York: Interscience Publishers.

Boyce, R. P. \& Howard-Flanders, P. (1964). Genetic control of DNA breakdown and repair in Escherichia coli treated with mitomycin C or ultraviolet light. Z. VererbLehre 95, 345.

Coughlin, C. A. \& Adelberg, E. A. (1956). Bacterial mutation induced by thymine starvation. Nature, Lond. 178, 531.

Gallant, J. \& Suskind, S. R. (1961). Relationship between thymineless death and ultraviolet inactivation in Escherichia coli. J. Bact. 82, 187.

GAREN, A. \& Zinder, N. D. (1955). Radiological evidence for partial genetic homology between bacteriophage and host bacteria. Virology 1, 347.

HARM, W. (1963). On the relationship between host cell reactivation and u.v. reactivation of u.v. inactivated phages. Z. VererbLehre 94, 67.

HART, M. G. R. (1966). Thymine starvation and genetic damage in Escherichia coli к 12. J. gen. Microbiol. 45, 489.

Howard-Flanders, P., Simpson, E. \& Theriot, L. (1964). The excision of thymine dimers from DNA, filament formation and sensitivity to ultra violet light in Escherichia coli $\mathrm{K} 12$. Mutation Res. 1, 219.

Howard-Flanders, P., Boyce, R. P., Simpson, E. \& Theriot, L. (1962). A genetic locus in E. coli K 12 that controls the reactivation of u.v.-photoproducts associated with thymine in DNA. Proc. natn. Acad. Sci., U.S.A. 48, 2109.

JACOB, F. \& Wollman, E. L. (1958). Genetical and physical determinations of chromosomal segments in Escherichia coli. Symp. Soc. exp. Biol. 12, 75.

MATTERn, I. E., VAN WINDEN, M. P. \& RoRsCH, A. (1965). The range of action of genes controlling radiation sensitivity in Escherichia coli. Mutation Res. 2, 111.

Rassmussen, R. E. \& Painter, R. B. (1963). On the early onset of thymineless death occurring after exposure to ultraviolet light. Biochim. biophys. Acta 76, 157.

SAUERBIER, W. (1961). The influence of 5-bromodeoxyuridine substitution on u.v. sensitivity, host cell reactivation and photoreactivation in $\mathrm{T} 1$ and $\mathrm{P} 22 \mathrm{H} 5$. Virology 15, 465.

SetLow, R. B. \& CARRIER, W. L. (1961). The disappearance of thymine dimers from DNA: an error correcting mechanism. Proc. natn. Acad. Sci., U.S.A. 51, 226.

TESSMAN, I. \& OZAKI, T. (1957). Multiplicity reactivation of bacteriophage T1. Virology 4, 315. 